\title{
The relationship between stock market development, business cycle and risk of banks
}

\author{
Iraj Moghadasi ${ }^{a}$ and Vahideh Tabibi $\operatorname{Rad}^{b^{*}}$
}

\begin{abstract}
${ }^{a}$ Masters in Accounting, Department of Accounting, College of Human Science, Saveh Branch, Islamic Azad University, Saveh, Iran ${ }^{b}$ Instructor, Department of Accounting, College of Human Science, Saveh Branch, Islamic Azad University, Saveh, Iran

C H R O N I C L E

Article history:

Received August 3, 2018

Received in revised format

August 232018

Accepted September 142018

Available online

September 142018

Keywords:

Market development

Banks

Tehran Stock Exchange

Financial development

\section{A B S T R A C T}

The purpose of this research is to investigate the relationship between stock market development, business cycle and risk of the banks. The statistical population of the study is all banks whose shares were accepted in Tehran Stock Exchange from 2010 to 2015 . The study selects 10 banks, which were active throughout the entire research period on the stock market. The research data were extracted from the financial statements of the companies and analyzed using regression models based on panel data. The research findings show that there was a direct and significant relationship between stock market development and risk of banks. In addition, the effect of stock market development on risk of banks was different in the presence or absence of a crisis, and the financial crisis in banks reduced the impact of the financial development on the risk of banks. The results also show that during the periods of commercial boom, the effect of the financial market development on the risk of banks was more than the periods of the recession.
\end{abstract}

\section{Introduction}

Financial markets play essential role for the development of the economy and it can help businesses develop their markets (Greenwald \& Stiglitz, 1993; Hope \& Langli, 2010). The positive effects of the securities on economic development, including increasing the incentive for investment through risk reduction, risk pricing and liquidity risk facilitation, and the mobilization of deposits, are relatively high. In fact, some economists believe that the difference between developed and underdeveloped economies is evident not in advanced development technologies, but in the presence of integrated financial markets (Erina \& Lāce, 2011). The business cycle of the reversible (repeatable) economy is the process in which the variables are moving in motion (Pagano, 1993). The initial analysis of business cycles shows that each phase of the economy would create the next stage. An economic leap (the boom) will create the next economic downturn; that stagnation will create the next boom, and the economy will endure forever in a reliant cycle (Galí, 2008).

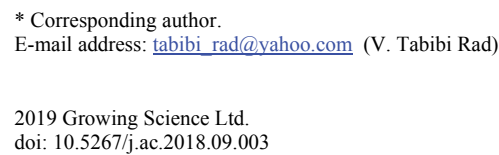


There are literally different studies on the relationship between financial market development and risk of market. Berger and Udell (1998) investigated the status of financing firms during the economic growth in private equity and debt markets and explained the sources of business finance. Levine (1999) described, in a comprehensive study, the effect of financial system on economic growth and concentrated on the ties between growth and the quality of the functions provided by the financial system.

According to Albertazzi and Gambacorta (2009), an essential element of the macro-prudential investigation is to figure out the relationship between business cycle fluctuations and banking sector profitability and how this association could be influenced by structural characteristics. Beck and Levine (2004) studied the effect of stock markets and banks on economic growth from 1976 to 1998 and reported that stock markets and banks positively influence the economic growth. Acharya and Naqvi (2012) developed a theory, which explained the relationship between the bank liquidity and risk taking over the business cycle.

Demirgüç-Kunt and Detragiache (1998) discussed the determinants of banking crises in developing and developed countries. They recommended that crises would likely appear when the macroeconomic environment becomes poor, specifically when growth was low and inflation was high. In addition, high real interest rates were associated with systemic banking sector problems, and there was an evidence that vulnerability to balance of payments crises could play an essential role. Almazari (2014) studied the internal factors influencing on profitability of banks by comparing the profitability of the Saudi and Jordanian banks based on the internal factors for estimations.

Chortareas et al. (2012) examined the effect of the announcements of floating and/or devaluating the exchange rate on stock returns in three MENA countries after the financial crises they experienced. They found clear evidence of abnormal volatility and abnormal returns because of the floating of the Egyptian and Turkish exchange rates in 2003 and 2001, respectively. Vithessonthi and Tongurai (2015) studied the impact of the firm size on the leverage-performance relationship during the financial crisis of 2007-2009.

\section{The proposed method}

The purpose of this research is to investigate the relationship between financial market development, business cycle and risk of the banks. This research is descriptive-correlative method and is of applied research type. The statistical population of the study is all banks whose shares were accepted in Tehran Stock Exchange between 2010 and 2015. The study selects 10 banks, which were active throughout the entire research period on the stock market.

According to the research, the following hypotheses are presented:

- First hypothesis: Financial market development has a direct relationship with the risk of banks.

- Second hypothesis: The financial crisis of the banks modifies the intensity of the relationship between the development of stock markets and the risk of banks.

- The third hypothesis: the business cycle moderates the link between the development of the stock markets and the risk of banks.

The research data were extracted from the financial statements of the companies and analyzed using regression models based on panel data. Table 1 demonstrates some basic information for the selected banks. 
Table 1

The results of some basic information

\begin{tabular}{lcccccc}
\hline Variable & Symbol & Mean & Median & Maximum & Minimum & Std. deviation \\
\hline Leverage & LEV & 0.481725 & 0.488448 & 0.607909 & 0.357407 & 0.06908 \\
Stock market development & SMD & 0.119474 & 0.12057 & 0.138556 & 0.101458 & 0.015396 \\
Cycle & CYCLE & 0.5 & 0.5 & 1 & 0 & 0.504219 \\
Crisis & CRISIS & 0.166667 & 0 & 1 & 0 & 0.375823 \\
Log of Total assets & LNTA & 15.18764 & 15.2893 & 16.8878 & 13.4076 & 0.960078 \\
Liquidity & LIQ & 0.420798 & 0.441405 & 0.599993 & 0.202467 & 0.122366 \\
Log of leverage to total assets & LLRTA & 0.079531 & 0.078407 & 0.109888 & 0.050894 & 0.017223 \\
Return on assets & ROA & 0.314009 & 0.335703 & 0.487365 & 0.152711 & 0.095547 \\
Ratio of import to export & TRADE & 1.075585 & 1.058515 & 1.19138 & 0.92966 & 0.09086 \\
\hline
\end{tabular}

The generalized Dickey Fuller test was used in this study to find out whether the data were stationary or not. This test examines the hypothesis of the existence of unit root in serial quantities. The results of this test are presented in Table 2. As we can observe from the results of Table 2, all data are stationary when the level of significance is five percent. Therefore, the behavior of the values of the variables will not change over time.

Table 2

The results Dickey Fuller

\begin{tabular}{lccc}
\hline Variable & Symbol & Dickey Fuller & P-Value \\
\hline Leverage & LEV & 36.7754 & 0.0124 \\
Stock market development & SMD & 15.0797 & 0.0118 \\
Cycle & CYCLE & 40.8688 & 0.0039 \\
Crisis & CRISIS & 34.0173 & 0.0260 \\
Log of Total assets & LNTA & 48.7258 & 0.0097 \\
Liquidity & LIQ & 34.9195 & 0.0145 \\
Log of leverage to total & LLRTA & 31.0649 & 0.0443 \\
Return on assets & ROA & 36.7754 & 0.0124 \\
Ratio of import to export & TRADE & 15.0797 & 0.0118 \\
\hline
\end{tabular}

Prior to fitting the regression model to determine the panel or integrity of the model, Chow or F-test is used. Hausman's test examines the fixed or randomized assumption of cross-sectional effects in the model. The results of Chow test is presented in Table 3.

Table 3

The results of Chow test

\begin{tabular}{cccc}
\hline Test & Statistics & Degree of freedom & P-Value \\
\hline Chow & 0.980554 & $(9,40)$ & 0.4706 \\
\hline
\end{tabular}

Considering the significance level of Chow test for determining the significance of cross-sectional effects in the research model, the significance level of this test is greater than the error of 0.05 ( $p$-value $=0.4706$ ). Therefore, Hausman test for determining the type of effects in the model is not necessary. The proposed study of this paper uses the following regression model,

$$
\begin{gathered}
\operatorname{LnLEV}_{\mathrm{i}, \mathrm{t}}=\beta_{0}+\beta_{1} \operatorname{LnSMD}_{i, \mathrm{t}}+\beta_{2} \text { Cycle }_{i, \mathrm{t}}+\beta_{3} \text { Crisis }_{\mathrm{i}, \mathrm{t}}+\beta_{4} \operatorname{LnSMD}_{\mathrm{i}, \mathrm{t}} \operatorname{Cycle}_{\mathrm{i}, \mathrm{t}}+\beta_{5} \operatorname{LnSMD}_{\mathrm{i}, \mathrm{t}} \operatorname{Crisis}_{\mathrm{i}, \mathrm{t}}+\beta_{6} \operatorname{LnTA}_{\mathrm{i}, \mathrm{t}} \\
+\beta_{7} \operatorname{LnLIQ}_{\mathrm{i}, \mathrm{t}}+\beta_{8} \operatorname{LnLLRTA}_{\mathrm{i}, \mathrm{t}}+\beta_{9} \operatorname{LnROA}_{\mathrm{i}, \mathrm{t}}+\beta_{10} \operatorname{LnTrade}_{\mathrm{i}, \mathrm{t}}+\varepsilon_{\mathrm{i}, \mathrm{t}}
\end{gathered}
$$

In model (1), Ln represents natural logarithm. LEV represents the leverage, SMD, Cycle, Crisis, TA, LIQ, LLRTA, ROA and Trade are defined in Table 1. Here, the variable of the financial crisis is a dummy variable, which receives the value of zero and one only, and 1 represents the existence of financial crisis and zero, otherwise. The trade cycle variable is also a dummy variable with zero and one value, where one represents the commercial boom period and zero represents recession. Finally, $\varepsilon$ represents the residuals and describes the effects of other unknown variables on dependent variable. 


\section{The results}

In this section, we present the results of the implementation of the Eq. (1) on the data from the selected banks in Tehran Stock Exchange. Table 4 demonstrates the results.

\section{Table 4}

The results of the regression estimates

\begin{tabular}{|c|c|c|c|c|c|}
\hline Independent variable & & Coefficient & t-value & Sig. & VIF \\
\hline LNSMD & & 1.029104 & 3.23861 & 0.0004 & 1.49336 \\
\hline CYCLE & & -2.247752 & -2.72681 & 0.0088 & 4.099881 \\
\hline CRISIS & & -1.250227 & -1.684985 & 0.0984 & 3.316175 \\
\hline LNSMD*CYCLE & & 1.014583 & 2.58533 & 0.0128 & 4.459136 \\
\hline LNSMD*CRISIS & & -0.61133 & -2.496702 & 0.0231 & 3.388128 \\
\hline LNTA & & -0.074038 & -2.808155 & 0.0071 & 1.465435 \\
\hline LNLIQ & & 0.109978 & 1.33281 & 0.1888 & 1.490745 \\
\hline LNLLRTA & & 0.153679 & 1.577133 & 0.1212 & 1.268358 \\
\hline LNROA & & 0.026835 & 0.374179 & 0.7099 & 1.241098 \\
\hline LNTRADE & & -0.422375 & -0.623804 & 0.5356 & 6.16331 \\
\hline $\mathrm{C}$ & & 3.142371 & 2.153114 & 0.0363 & - \\
\hline Test & Statistics (P-value) & & & & \\
\hline F-value & $4.787426(0.000087)$ & & & & \\
\hline Jarque Bera & $0.18577(0.9112)$ & & & & \\
\hline Adjusted R-Square & 0.390963 & & & - & \\
\hline Durbib-Watson & 2.234799 & & & - & \\
\hline
\end{tabular}

The first hypothesis: To test this hypothesis, the effect of stock market development on bank risk has been investigated. Since the significance level of the effect of this variable in the research model is smaller than the error of 0.05 ( $p$-value $=0.0004$ ), it can be concluded that financial market development has had a significant effect on the risk of banks. Also, according to the coefficient of the effect of this positive variable (beta $=0.0291$ ), it can be expected that with the increase of financial market development, the risk level of the banks will increase. Therefore, there is a direct and significant relationship between the development of the stock markets and the risk of banks. Therefore, the first hypothesis of the research is confirmed at the error level of 0.05 .

The second hypothesis: In order to test the second hypothesis, the effect of financial crisis and stock market development on bank risk has been investigated. Considering the significant level of this interaction in the research model which is smaller than the error of 0.05 ( $p$-value of 0.0231 ), it can be concluded that the development of financial market and financial crisis of banks had a significant effect on bank risk. Since the variable of the financial crisis is a dummy variable, which receives zero and one only, it can be concluded that situation 1 (existence of financial crisis) for this variable resulted in the effect size equal to 0.417774 on bank risk. The zero state for this variable (absence of crisis) would have the effect of eliminating the effect of LNSMD $\times$ CRISIS from the research model and the size of the effect of the financial market development on the banks' risk is equal to its direct effect of 1.49104. Therefore, it can be concluded that the effect of the financial market development on the risk of banks is different under the conditions of existence or absence of crisis, and the occurrence of financial crisis in banks has led to a decrease in the level of financial development impact on the risk of banks. Therefore, the second hypothesis of the research is approved at the error level of 0.05 .

In order to test third hypothesis, the interaction between the business cycle and the development of financial market on the risk of banks has been investigated. Considering the significance level of this interaction in the research model which is smaller than 0.05 (p-value $=0.128$ ), it can be concluded that the development of financial market and commercial cycle of banks had a significant risk-based interaction with banks. Since the trade cycle index of the variable is a dummy variable with zero and one value, it can be concluded that condition 1 (commercial boom period) for this variable will influence on the risk of banks. While the zero status for this variable (business recession) resulted in the removal of the effect of LNSMD $\times$ CYCLE from the research model and the size of the effect of 
the financial market development on the banks' risk is equal to its direct effect of 1.09104. Therefore, it can be concluded that the effect of financial market development on the risk of banks is different under the conditions of business boom and recession and in the periods of commercial boom, the effect of financial market development on bank risk was more than the period of a recession. Therefore, the third hypothesis of the research has been approved at the error level of 0.05 .

In examining the significance of the whole model, considering the fact that the probability value of the analysis of F-value is less than 0.05 , with $95 \%$ confidence, the overall model's significance is confirmed. The coefficient of the model determination also indicates that $39.09 \%$ of the changes in the risk of banks are explained by the variables entered in the model. The result of Durbin-Watson statistics shows that there was no autocorrelation. The results of the Jarck-Bra test for confirmation of the normal distribution of the experimental components of the error components with a significant level of 0.912 show that the components of the model error were normal. The value of the VIF index, which is calculated for the estimation of non-coherence among independent variables of research, is less than the critical value of 10 , which indicates that there was no strong correlation among the independent variables of the research. Therefore, it can be assumed that the accuracy of the coefficients of influence of independent variables in the research model are not affected by the internal relationships of independent variables. Therefore, it can be assumed that the initial assumptions of regression exist and that the model's results can be cited in determining the effects. Fig. 1 shows the empirical distribution of model error components and their distribution patterns.

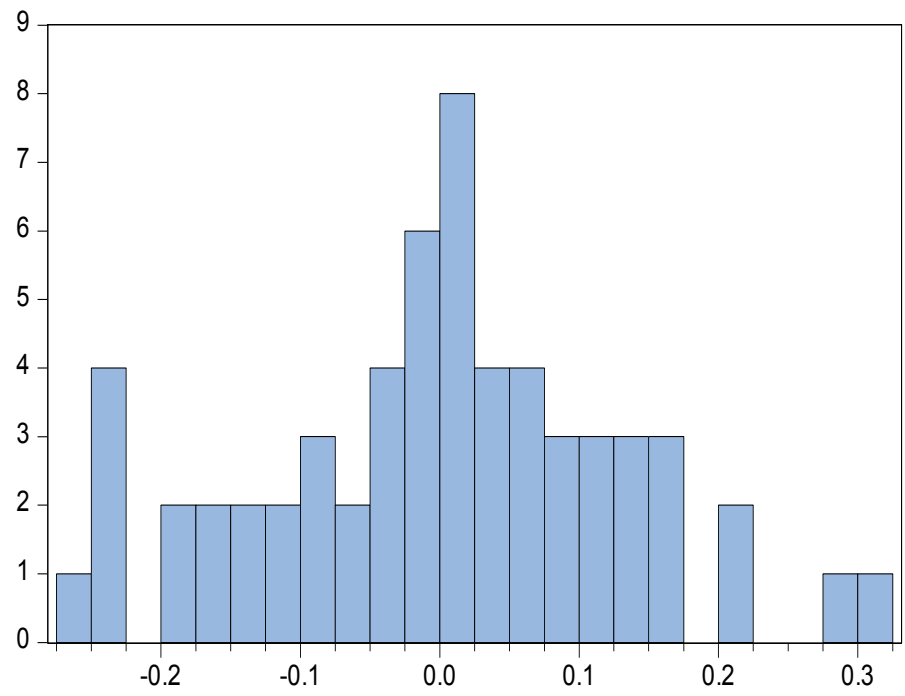

\begin{tabular}{|c|c|}
\hline \multicolumn{2}{|c|}{$\begin{array}{l}\text { Series: Residuals } \\
\text { Sample } 160 \\
\text { Observations } 60\end{array}$} \\
\hline Mean & $-3.79 e-17$ \\
\hline Median & 0.007611 \\
\hline Maximum & 0.311609 \\
\hline Minimum & -0.251731 \\
\hline Std. Dev. & 0.129893 \\
\hline Skewness & -0.008312 \\
\hline Kurtosis & 2.727912 \\
\hline Jarque-Bera & 0.185770 \\
\hline Probability & 0.911298 \\
\hline
\end{tabular}

Fig. 1. Experimental distribution of model error components

\section{Conclusion}

In this research, we have performed an assessment on the relationship between the development of stock markets, the business cycle and the risk of banks on the information of selected banks whose shares were traded on Tehran Stock Exchange. The proposed study has implemented a regression analysis to examine the effects of different variables on logarithm of leverage. The survey has concluded that there was a direct and significant relationship between the development of the stock markets and the risk of banks. Moreover, the effect of the stock market development on the risk of banks was different under the conditions of existence or absence of crisis. In fact, the occurrence of financial crisis in banks has led to a decrease in the level of financial development impact on the risk of banks. Finally, the effect of stock market development on the risk of banks was different under the conditions of business boom and recession. In fact, in the periods of commercial boom, the effect of 
stock market development on bank risk was more than the period of a recession. The results of this survey were consistent with the findings of Vithessonthi and Tongurai (2015).

\section{Acknowledgement}

The authors would like to thank the anonymous referees for constructive comments on earlier version of this paper.

\section{References}

Acharya, V., \& Naqvi, H. (2012). The seeds of a crisis: A theory of bank liquidity and risk taking over the business cycle. Journal of Financial Economics, 106(2), 349-366.

Albertazzi, U., \& Gambacorta, L. (2009). Bank profitability and the business cycle. Journal of Financial Stability, 5(4), 393-409.

Almazari, A. A. (2014). Impact of internal factors on bank profitability: Comparative study between Saudi Arabia and Jordan. Journal of Applied Finance and Banking, 4(1), 125.

Beck, T., \& Levine, R. (2004). Stock markets, banks, and growth: Panel evidence. Journal of Banking \& Finance, 28(3), 423-442.

Berger, A. N., \& Udell, G. F. (1998). The economics of small business finance: The roles of private equity and debt markets in the financial growth cycle. Journal of Banking \& Finance, 22(6-8), 613673.

Chortareas, G., Cipollini, A., \& Eissa, M. A. (2012). Switching to floating exchange rates, devaluations, and stock returns in MENA countries. International Review of Financial Analysis, 21, 119-127.

Demirgüç-Kunt, A., \& Detragiache, E. (1998). The determinants of banking crises in developing and developed countries. Staff Papers, 45(1), 81-109.

Eriņa, J., \& Lāce, N. (2011). Latvian Commercial Bank Profitability Indicators. publication. editionName, 1316-1325.

Galí, J. (2008). Monetary policy, inflation, and the business cycle: an introduction to the new Keynesian framework.

Greenwald, B. C., \& Stiglitz, J. E. (1993). Financial market imperfections and business cycles. The Quarterly Journal of Economics, 108(1), 77-114.

Hope, O. K., \& Langli, J. C. (2010). Auditor independence in a private firm and low litigation risk setting. The Accounting Review, 85(2), 573-605.

Levine, R. (1999). Financial development and economic growth: views and agenda. The World Bank.

Pagano, M. (1993). Financial markets and growth: an overview. European economic review, 37(2-3), 613-622.

Vithessonthi, C., \& Tongurai, J. (2015). The effect of firm size on the leverage-performance relationship during the financial crisis of 2007-2009. Journal of Multinational Financial Management, 29, 1-29.

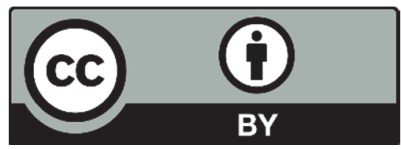

(C) 2019 by the authors; licensee Growing Science, Canada. This is an open access article distributed under the terms and conditions of the Creative Commons Attribution (CC-BY) license (http://creativecommons.org/licenses/by/4.0/). 